\title{
Measurements of ion temperature for string plasma and sheet plasma
}

\section{ストリング・プラズマ、シート・プラズマのイオン温度測定}

Teruo YAJIMA, Naoto SUZUKI and Sigeyasu SAKAMOTO

Department of Nuclear Engineering,School of Engineering,

Akihi ro MATSUBARA and Goichi OHMAE

Department of Physics,School of Science,

Kazutaka KAWAMURA and Kazuo TAKAYAMA

Institute of Research and Development,

Tokai University, 1117 Kitakaname,Hiratsuka,Kanagawa,259-12 Japan

TEL:81-58-1211(EX.5305), FAX:81-58-1203

( Accepted for publication 16 November 1995)

Two machines, called "String Plasma Device(SPD) and "Isotope Separation Device(ISD),were used for the present work. Among many plasma parameters the ion temperature, $T_{i}$, is not yet determined for these machines. The $T_{i}$ obtained from the emission spectrum is $2-13 \mathrm{eV}$ for the SPD and $1-4 \mathrm{eV}$ for the ISD.

Key words : String plasma,Sheet plasma,Ion temperature,Doppler effect

\section{I.INTRODUCTION}

プラズマ実験棟には2台の直線型プラズマ生成装置 [ストリング・プラズマ生成装置:SPD (String Plasma Device)、シート・プラズマ生成装置: ISD (Isotope Separation Device)] がある。これらの装置はTP-D (Test Plasma generated by DC discharge)型プラズ マ源を改良したもので東海大学独自のものである。生 成されるプラズマの形状は、ストリング・プラズマ生 成装置では直径 $1 \mathrm{~cm}$ 弱の紐状、シート・プラズマ生成装 置では厚さ $1 \mathrm{~cm}$ 、幅 $3 \mathrm{~cm}$ 程度の板状となっている。1, 2

現在のところ、これらのプラズマのイオン温度は詳 しく測定されていない。イオン温度は、プラズマの挙 動を解析する上で重要なパラメーターである。イオン 温度は、ファラデーカップ等のエネルギー分析器また は分光測定から求めることができる。しかしエネル ギー分析器は、磁場中では正確に測定することができ ない。そこで本研究では分光測定によって各々のプラ ズマのイオン温度を測定することを目的とした。

\section{II .SETUP}

プラズマ中のイオンが発する線スペクトルは、熱運 動によってそのスペクトル線に広がり(ドップラー広が り）を生じる。このドップラー広がりを測定することに よりプラズマ中のイオンの温度を求めることができる。

ドップラー効果によって広がったスペクトルの半值

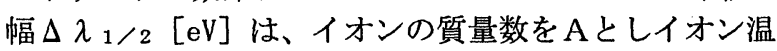
度を $\mathrm{T}_{\mathrm{i}}[\mathrm{eV}]$ 、波長 $\lambda[\AA]$ で表せば

$$
\Delta \lambda_{1 / 2}=7.7 \times 10^{-5} \lambda_{0} \sqrt{\frac{T_{t}}{A}}
$$

となり、イオン温度は半値幅を用いて

$$
T_{i}=1.7 \times 10^{8} \mathrm{~A}\left(\frac{\Delta \lambda_{1 / 2}}{\lambda_{0}}\right)^{2}
$$

で与えられる。 ${ }^{3-5}$

今回の測定で使用したストリング・プラズマ生成装 置とシート・プラズマ生成装置、各々の仕様をTable1 に示す。Table1に示した電子密度 $\mathrm{N}_{\mathrm{p}}$ 、電子温度 $\mathrm{T}_{\mathrm{e}}$ は、 以前にラングミュアプローブで測定されたものである。 ストリング・プラズマ生成装置での測定は、放電気体 をアルゴン、アルゴンの流量 $\left(\mathrm{Q}_{\mathrm{Ar}}\right)$ は $0.3 \mathrm{sccm}$ 、放電電 流(Id)を4、8、12Aとし、磁束密度を(B) を0.5、1、2、 $3 \mathrm{kG}$ と変化させて行った。シート・プラズマ生成装置で の測定は、放電気体をアルゴン、アルゴンの流量 $\left(Q_{\mathrm{A}} \mathrm{r}\right)$ は10sccm、放電電流 (Id) を8、10、20A とし、磁束密度 (B) を0.93、1.23、1.85(一部0.63から) $\mathrm{kG}$ と変化させて 行った。測光系には3枚の鏡, それぞれ1個ずつのレン ズと色消しレンズを用いた。色消しレンズは分光器の 前に設置した。イオン温度を求めたスペクトル波長は、

TABLE1.Specification of SPD and ISD

\begin{tabular}{|l|l|l|}
\hline & $\begin{array}{l}\text { ストリング・ } \\
\text { プラズマ生成装置 }\end{array}$ & $\begin{array}{l}\text { シート・プラズマ } \\
\text { 生成装置 }\end{array}$ \\
\hline 放電電流 $\mathrm{Id}$ & $\sim 12(\mathrm{~A})$ & $\sim 20(\mathrm{~A})$ \\
\hline 磁束密度 $\mathrm{B}$ & $\sim 3(\mathrm{kG})$ & $\sim 1.85(\mathrm{kG})$ \\
\hline 放電領域圧力 $\mathrm{Ps}$ & $\sim 1(\mathrm{Torr})$ & $\sim 1(\mathrm{Torr})$ \\
\hline 実験領域圧力 $\mathrm{P}$ & $\sim 10^{-5}(\mathrm{Torr})$ & $\sim 10^{-4}(\mathrm{Torr})$ \\
\hline 電子密度 $\mathrm{N}_{\mathrm{p}}$ & $\sim 10^{17}\left(/ \mathrm{m}^{3}\right)$ & $\sim 10^{18}\left(/ \mathrm{m}^{3}\right)$ \\
\hline 電子温度 $\mathrm{Te}$ & $\sim 14(\mathrm{eV})$ & $\sim 5(\mathrm{eV})$ \\
\hline
\end{tabular}




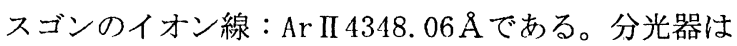
SPEX1104 (焦点距離0.85m)、検出器は光電子増倍管 (浜 松ホトニクスR928）を用いた。

\section{III.RESULTS}

ストリング・プラズマ生成装置での測定結果を Figure1に示す。Figure1では磁束密度を横軸とし、そ れぞれの放電電流でのイオン温度を縦軸にとった。 Figure1では放電電流4Aと8Aではイオン温度は2から

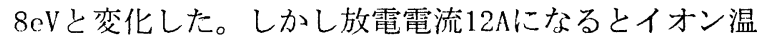
度は 3 から $13 \mathrm{eV}$ と急激な上昇がみられる。特に磁束密度 $3 \mathrm{kG}$ の時にイオン温度の上昇が強くなるのがわかる。こ れは磁束密度を上げることによって、放電領域内のプ ラズマが陽極周辺に集中し、放電領城压力が上昇した ためにプラズマが加熱され易くなり、イオン温度が上 昇したものと考えられる。Fig. 2.に放電領域圧力を横 軸、イオン温度を縦軸にとったグラフを示す。

Fi gure2では各放電電流で一番低いイオン温度から順に、 それぞれ磁束密度0.5、1、2、3kGとなっている。この グラフから放電電流、磁束密度と放電領域圧力が比例 していることがわかる。また放電領域压力とイオン温 度が同様に比例していることがわかる。このことから も前述したプラズマ中のイオンの加熱渦程が起こって いるものと考えられる。

Figure3にシート・プラズマ生成装置での測定結果を 示す。シート・プラズマではイオン温度は、1から $4 \mathrm{eV}$ となり、ストリング・プラズマの様なイオン温度の 急激な上昇はみられなかった。また、シート・プラズ マ生成装置では磁束密度を上げても放雷領域圧力の上 昇は起こらなかった。よって、これはシート・プラズ マ生成装置はストリング・プラズマ生成装置に比べ、 陽極が非常に大きいために前述のプラズマ中のイオン の加熱が行われなかったためと考えられる。

これ以上の詳しい解析には，プラズマの生成機構、 特に浮動電極内について詳しく調べる必要がある。

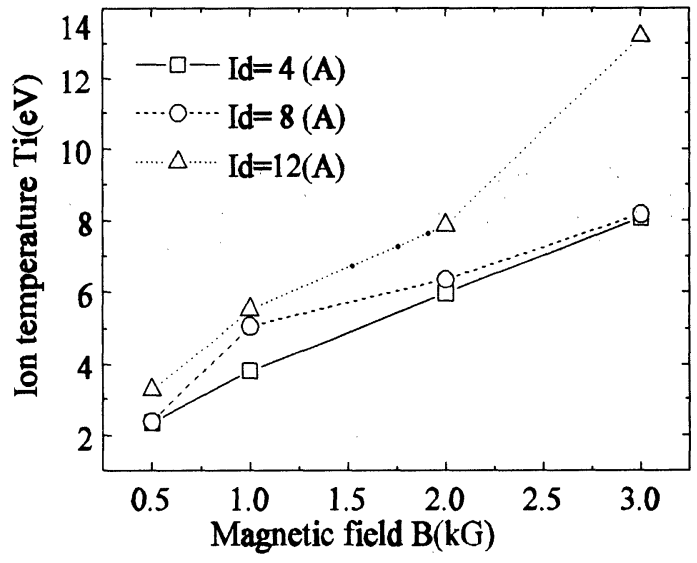

FIG. 1. The relation of magnetic field and ion temperature.

Devicd:SPD, Gas: $\mathrm{Ar}, \mathrm{Q}(\mathrm{Ar})=0.3 \mathrm{sccm}, \lambda=4348.063 \AA$

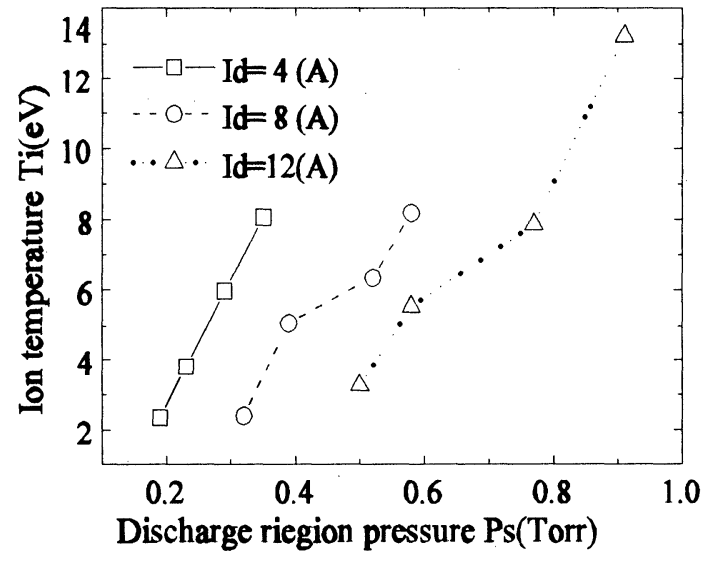

FIG.2.The relation of discharge ricgion pressure and ion temperature.

Device:SPD, Gas: $\mathrm{Ar}, \mathrm{Q}(\mathrm{Ar})=0.3 \mathrm{sccm}, \lambda=4348.063 \AA$

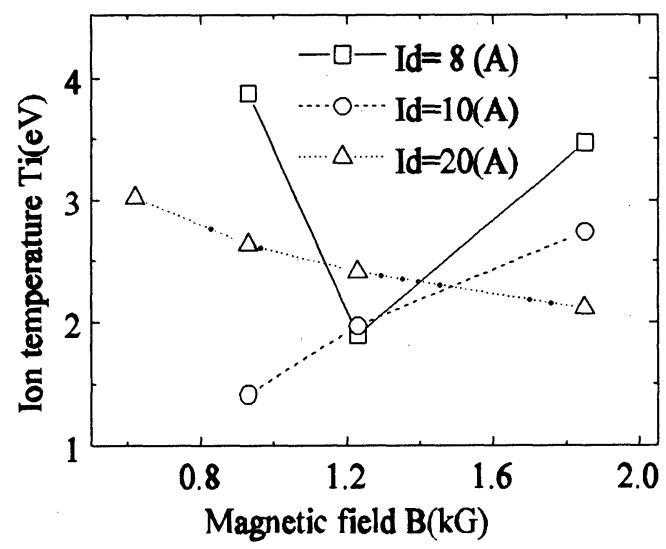

FIG.3. The relation of magnetic ficld and ion temperature Device:ISD,Gas:Ar, $Q(\mathrm{Ar})=10 \mathrm{sccm}, \lambda=4348.063 \AA$

\section{REFERENCES}

${ }^{1}$ T.Tanikawa,T.Noguchi,S.Harakawa,H.Watanabe,K.Yamauchi, K.Sunako,K.nanri and K. Takarama:in Proceedings of Internationl Conference on Plasma Physics (1989,New Delhi) Vol. III,p. 1157

${ }^{2}$ K. Takavama,M.Otuka,Y.Tanaka,K.Ishii and Y.Kubota:in Proceeding of the Eigth International Conference on Phenomena in Ionized Gases(1967,Vienna)Vol. I p. 551 ${ }^{3}$ The japan society of plasma science and nuclear fusion research editing,Purazumashindan no kiso(Nagoya univ. pablication society, 1990). ${ }^{4}$ Y.Fujioka editing.Bunkougaku(Koudanshra. 1967) ${ }^{5}$ H.R.Griem,Plasmaspectroscopy(McGrawHill.New York, 1964)

'95 SAS Intelligent Symposium 